\title{
Practice of Curriculum Teaching Reform on Green Transport Packaging
}

\author{
Yabo Fu, Haowei He, Lijuan Liang*, Lizheng Zhang, Guorong Cao \\ School of Printing and Packaging Engineering, Beijing Institute of Graphic Communication \\ Beijing, China 102600
}

\begin{abstract}
As a compulsory lesson for undergraduate students majored in packaging engineering, Green Transport Packaging is a multi-disciplinary and practical course. To improve the teaching effect of this curriculum both theoretically and practically, some work was done to enhance students' competitive ability on professional packaging engineering training. This paper demonstrates the thinking and exploration of teaching reform on this Green Transport Packaging course from the aspects of teaching materials and staff construction, teaching tools and methods reform, teaching practice and curriculum assessment methods, so that students get a more comprehensive knowledge system in theory and practice. After years' practice and curriculum system optimization, both the teaching and learning effects obtained significant improvement. Students are more capable of using six-step transport packaging design method and making good package practically.
\end{abstract}

Keywords-Packaging education; Transport packaging; Teaching methods; Curriculum reform

\section{INTRODUCTION}

Teaching is challenging career which require abundant knowledge, guiding methodology, technology based teaching tools, teaching skills, good communication skills and also much efforts on both input and output knowledge. Green Transport Packaging is a strong theoretical and practical professional compulsory course in packaging engineering. It mainly teaches the basic concepts of packaging mechanics and rheology, circulation environment of the packaging parts, Fragility theory, six-step design of buffer packaging and modern logistics transport packaging technology and other related aspects. Students can master the basic idea of product packaging design, skilled use the buffer packaging design basic methods to guide the specific practice about the products of buffer and anti-vibration packaging design through this course study. The curriculum, in content and structure, contains both theoretical and technical principles, material properties and packaging techniques which are closely integrated with practices in buffer packaging design. So, it is necessary to make curriculum and teaching methods reform to keep up with the development of packaging industry new technology trend [1-4].

In our last version of professional training program of packaging engineering of Beijing Institute of Graphic Communication, packaging engineering was divided into two professional directions as packaging technology development and packaging system design. Combining with the features of packaging engineering in our institute, this paper expresses some thoughts and useful explorations in course construction and teaching reform of Green Transport Packaging during the past 10 years.

\section{TEACHING MATERIALS AND STAFF TEAM CONSTRUCTIONS}

\section{A. Teaching materials construction}

There are two main textbooks including logistics packaging design and green packaging for this Green Transport Packaging professional packaging major course. Combining with the packaging engineering professional experimental instructions edited by course instructor and years of teaching materials, we created a more useful transport packaging courseware and lectures, including course learning outline, main parts, questions, homework, quiz and etc, so as to achieve full coverage of the main knowledge points, basically meet the requirements of students on this course.

\section{B. Teaching staff construction}

After more than 10 years of teaching team construction, the transport packaging course in our institute has established a teaching team which guided by academic leaders, including one professor, two associate professors, two lecturers and two experimental teachers, to meet the undergraduate, graduate and vocational education in professional packaging and multilevel theoretical and practical teaching tasks.

As a member of the World Packaging Research Institute (IAPRI), Beijing Institute of Graphic Communication (BIGC) has been closely engaged with international packaging activities in recent years. For example, we invited Professor David, the editor of the International Packaging Professional Journal, and Dr. Thomas, former Packaging Research Institute leader, as our honorary Professors, and joined the packaging engineering professional team. They gave wonderful lessons or lectures to undergraduate students for green logistics transport packaging. Last year, these two professors presented wonderful lectures of "Packaging in Supply ChainsContradictions in Environmental Thinking" and "Containment Systems for Dangerous Goods" respectively, which introduced the latest research developments in the field of transport packaging and logistics, giving students access to communication opportunities with external professors and the 
master face to face, and this activity are welcomed by the students generally. Also, we invited 1-2 guest speakers from industries to give recent industry technologies. For example, we invited Dr. Huang, associate manager at a packaging design company. He is very rich on practical transport packaging design and test on white household appliances cushioning packaging, various shocks and vibration test from laboratory to road, so as to meet the real road logistics transport environment.

\section{TEACHING METHODS AND TEACHING METHODS REFORM}

\section{A. The application of network and multimedia teaching technology}

To achieve excellent teaching effect on this transport packaging course, our teaching team must require teachers to manage the whole process in pre-class, during class and afterclass. First of all, students are required to previously view about the contents that will be learned, and generally knows the relevant knowledge points. Secondly, teachers are required to focus on "student-centered" teaching during class, organizing the teaching content carefully, and some class questions and discussion sessions can be set in a certain proportion except the main points of the classroom to explain. In addition, students will be divided to several groups and guided to form an atmosphere that students discuss and debate with each other group, and also students interact with teachers in classroom. Finally, it is necessary to use the course teaching network platform to upload the learning courseware, afterschool thinking questions, quiz and review outline and other teaching materials to the network classroom, including the conceptual understanding, the basic title and ability improvement questions and others to meet the learning requirements in different levels and professional oriented.

In addition, the transport packaging courses involve that mathematical formula derivation, packaging structure and design, cushioning liner performance, package test and many of them need strong comprehensive. It is quite difficult to achieve satisfactory results by simple explanation. The processing of the course construction and reform, multimedia technology is used to make the animation and video multimedia courseware about the transport process of vibration, shock, the external environment, etc. It shows the main content of the course vividly from the visual and auditory intuitive, and deepens the impression of students, achieving a more satisfactory teaching effect.

\section{B. The use of research and heuristic teaching methods}

We are now entering a information based ear, many new technologies are emerging including artificial intelligence, big data, industry internet and etc. Together with the change of the outside world, teachers are asked to advance the teaching methods, to face the popularity of multimedia technology and information technology, and change our teaching style from the "talk good" to "teach good", in response to the country call that building a lifelong education system [5-6]. In the teaching process of this course, we should pay attention to apply the "research and heuristic" teaching methods in classroom teaching. Teachers should change the teaching mode of simple knowledge indoctrination, not only teach knowledge, but also teach the method of learning, so that students not only familiar with the course of knowledge points, but also master the way of learning the same course.

Therefore, we carried out many teaching researches, to encourage students engaged in teaching process, such as ask students questions in classroom, leads students to think, to form an effective communication with the students. At the same time, assist in heuristic teaching methods to increase the use of methods such as induction, analysis and synthesis, and cultivate students' ability to self-study, analyze problems and solve problems. These teaching methodologies were used alone or in combination with each other, depend on the actual classroom scene requirement.

\section{The application of case teaching method}

Some industry latest classic cases on logistics and green transport packaging are introduced into the teaching part which not only enriching the classroom teaching content and improving the teaching effect, but also enabling students have a growing interest and increasing the sense of identity of the professional. For example, a novel foldable multiple-use tray designs, to improve and load efficacy and reduce logistic cost, as well as multiple use function to replace the disposable tray. This packaging solution can realize the function to protect goods well and save our planet at the same time. The packaging case made students have a good understanding of the specific application of the knowledge of environmental friendly packaging technology and total packaging solution system design so as to optimize transport packaging design of the largest automotive and its parts and components using by civil and military products in heavy machinery packaging.

By using these packaging design case by case, from simple to complicated. After two or three packaging case study, we aimed to train the undergraduate students master the main design methodology, design and make buffering packaging by themselves gradually. Teachers are required to observe students and divided them to different levels, to led the fastlearners to higher level and put more efforts to encourage slow-learners to master the basic concepts and tools.

\section{The practice of packaging system design defence}

Teaching textbooks and other materials often time lag behind the actual level of development of the packaging industry, so we need to actively expand and obtained new teaching materials, so as to advance with industry progress. For example: being actively involved in industry seminars of the transport packaging organization (ISTA) in China, involved in solving product packaging design problems, and collect and organize useful information to update the teaching case timely [7-8]. In addition, after group presentation, teachers can collect and show the winners of the transport packaging and packaging structure design competition, analyze and discuss the advantages and disadvantages of these design in the classroom with the students to create a good atmosphere of classroom interaction, so that more students participate in classroom teaching and communication. Using the interactive teaching methods in the case of teaching, not only can increase students' interest of learning, and let 
students active learn and master knowledge points of the course in a relaxed atmosphere to achieve the effect of entertaining, but also this case of "complete packaging solution "will give student some helps for their future career.

\section{CURRICUlum PRACTICE TEACHING REFORM}

\section{A. Course experiment settings}

Packaging is a practical discipline with characteristics that multi-disciplinary cross, covering a wide range of knowledge. The primary purpose of transport packaging course, that is to protect the products as primary function in the process of logistics. Therefore, this curriculum set up eight hours' experimental parts in the years of practical teaching, and the specific content is as Table 1.

The content of the three practice teaching experiments in this course basically covers the main contents of the transportation packaging course, including the verification experiment, the comprehensive experiment and the design experiment, the upper level of the experiment is set up to enhance the students' comprehension to main teaching contents and buffer packaging design ideas.

TABLE I. EXPERIMENTAL COURSES

\begin{tabular}{|c|c|c|c|c|}
\hline Number & Project & Time & Main Content & Require and Purpose \\
\hline 1 & $\begin{array}{l}\text { Shock and vibration test } \\
\text { of packages }\end{array}$ & $\begin{array}{l}2 \text { hours/ Group } \\
\text { works }\end{array}$ & $\begin{array}{l}\text { Simulate the actual impact } \\
\text { strength; test the package; } \\
\text { and measure the impact } \\
\text { strength that the package can } \\
\text { withstand. }\end{array}$ & $\begin{array}{l}\text { a) Familiar with the working principle and } \\
\text { test methods of impact and collision } \\
\text { experiments; } \\
\text { b) Prepare for the experimental according } \\
\text { to the experimental instructions, and carry } \\
\text { out according to the steps; } \\
\text { c) Analyze data, write reports. }\end{array}$ \\
\hline
\end{tabular}

\section{B. Comprehensive design of the course}

This course has a comprehensive course design section, to focus on the student to access to information about the product characteristics, product damage boundary curve, impact and vibration theory model, six steps buffer packaging design tools and several cushioning material performance curves and the ability of mastering and flexible using.

At the same time, this course are designed to examine the students' ability on applying the basic materials such as "Packaging Materials Science", "Packaging Structure Design" and "Packaging and Decoration Design" to strengthen students' system design idea of "total packaging solution". Not only to protect goods, but also to fulfill the full functions of actual commercial requirements.

\section{Internship on transport packaging system design}

Packaging is multiple-discipline course which need many years training, so as to grow and become a packaging engineer. Only by theoretical and several experimental lessons are far behind the various real goods packaging actual requirement. So, after this course, a 3-6 month special internship at industry companies is needed, to obtained more skills and baseknowledge as advanced packaging engineer, if students want start a career on logistics and transport packaging system design.

\section{REFORM OF CURRICULUM ASSESSMENT METHODS}

\section{A. Course assessment method}

Green Transport Packaging is a curriculum that has many theory and calculation, involving a number of theoretical hypothesis model and the corresponding calculation formula. So, this course takes the form of open-book examinations to avoid rote learning, and strengthen the flexible use of knowledge and professional tools. The examination scores of this part accounted for $60 \%$, the others accounting for $40 \%$ which include the experimental part, course design, classroom attendance, homeworks, classroom performance. In addition, we set a certain incentive points to mobilize the enthusiasm of students for active preparation and participation in classroom discussions and effective answering questions to active classroom atmosphere, enhance the learning effect. After two rounds of teaching reform practice, we achieved a better classroom teaching effect. 


\section{B. Assessment method reform}

During the assessment of the course, we plan to set a certain free or exemption conditions for outstanding students, such as: pass through the intermediate level transport packaging engineer intermediate certification exam in International Safe Transit Association (ISTA) test, won the top prize of the National University Students Packaging Structure Design Competition ( $1^{\text {st }}$ author Completed), done research works and publish scientific papers on transport packaging, won high prize on innovation and entrepreneurship competition, as well as participate in other activities at the same level or above related with transport packaging technology. These students are given the qualification of free examination, and the course scores are directly rated as "A" for encouraging students to pursue self-study and actively participate in course-related practice.

\section{CONCLUSION}

This paper demonstrates some teaching reform efforts on Green Transport Packaging course. After several years' reform, we improved the teaching and learning effect by gradually teaching and curriculum reform, including the optimization of key knowledge points, curriculum design and the logistics and continuous development of transportation packaging new technology of, new materials and new standards, and combined with the practical teaching skills. The results shows the latest development concept and application of complete packaging solution. To summarize, improve, enrich, and improve teaching materials and practice reform to help students build knowledge systems and thus improve their practical ability on transport packaging system design and actual application. Only with continuous teaching reform, can we improve the professional packaging education and optimize education system, to enable students adapt to the changing requirements of technology fast development of packaging disciplines and personnel career training.

\section{ACKNOWLEDGMENT}

The work is supported by the packaging Engineering Teaching Team Construction program (No.22150116006/017), Jing-Jin-Ji Collaborative teaching reform Project (22150117020/008),Coordinative Innovation Project of Beijing Municipal Commission of Education (No.04190117019) and BIGC Packaging Advantage specialty construction project (22150117101).

\section{REFERENCES}

[1] Peng Guoxun. Logistics transport packaging design [M]. Beijing: Printing Industry Press, 2011. (In Chinese)

[2] Gao De. Exploration of the construction of packaging engineering specialty in the new century [J]. Journal of Beijing Institute of Graphic Communication, 2002,10 (1): 22. (In Chinese)

[3] Hua Guangjun,Yin Wei, Zhao Dejian. Green logistics transport packaging course practice teaching research $[\mathrm{J}]$. Journal of Hunan University of Technology, 2009,23 (2), 106-108. (In Chinese)

[4] Song Haiyan, Huang Liqiang.Transport packaging teaching reform research [J].Journal of Hunan University of Technology, 2009,14 (5): 126-127. (In Chinese)

[5] Yang Zubin, Dai Hongmin."New packaging solutions" new requirements for packaging personnel training [J].Packaging Engineering, 2009, 30 (9): 203-206.

[6] Zhou Jianwei, Hu Hongyan, Gao De, etc. Packaging Engineering Specialty practice teaching system integration and optimization [J] .China Printing and Packaging Research, 2013,4 (5): 69-74.

[7] Xiang Hong, Wu Ruomei, Liu Yuejun. Packaging Engineering professionals knowledge structure and innovation ability training research and practice $[\mathrm{J}]$. Journal of Hunan University of Technology, 2007 (2): 104- 107. (In Chinese)

[8] Tan Si Chao. Practical teaching and scientific research combined with innovative education model research [J]. Education Theory and Practice, 2007,27 (S1): 248-24 